\title{
Teresa Slaby
}

Wyższa Szkoła Menedżerska w Warszawie

e-mail: tsl@pnet.pl

\section{REKOMENDACJA KSIĄŻKI TOMASZA OLEJNICZAKA PT. KONSUMENCI SENIORZY WOBEC INNOWACJI PRODUKTOWYCH}

DOI: 10.15611/nit.2018.4.05

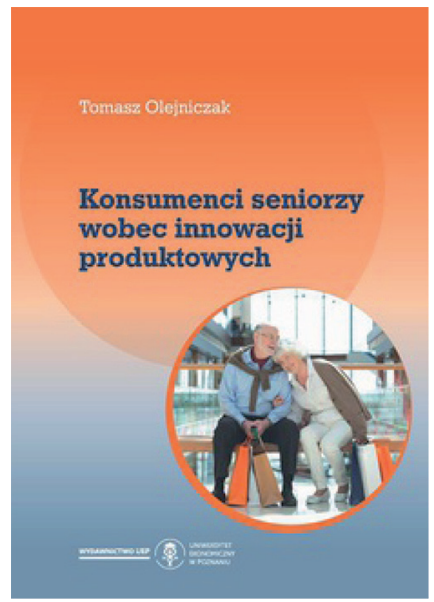

Recenzowana publikacja jest podsumowaniem wieloletnich badań autora, który jako pierwszy w Polsce zbadał, stosując wielowymiarową analizę statystyczna, postawy konsumpcyjne osób starszych wobec innowacji produktowej. Główny cel książki należy uznać za pionierski, a jego realizację, polegającą na rozpoznaniu empirycznym - za trudną ze względu na silnie zróżnicowaną populację seniorów. Ta grupa ludności jako obiekt zainteresowania stanowi wyzwanie dla kilku dziedzin nauki. Cel pracy odnosi się do badań nad konsumentem, nad uwarunkowaniami jego zachowań rynkowych i znaczeniem problematyki konsumenckiej w strategiach marketingowych przedsiębiorstw.

Książka ma istotny walor poznawczy w odniesieniu do zaspokojenia potrzeb coraz liczniejszej grupy ludności w Polsce, którą stanowią osoby w wieku 60+. Ma także wymiar aplikacyjny, bowiem prezentuje determinanty zachowań konsumpcyjnych seniorów na rynku wybranych produktów najszybciej rotujących, określanych jako FCMG (Fast Moving Consumer Goods). Opisane w niej czynniki mogą być ważne podczas konstruowania przez polskie przedsiębiorstwa nowej oferty rynkowej.

Cel główny niniejszej publikacji stanowi poszukiwanie determinant zachowań konsumpcyjnych seniorów. Badania, które rozpoczęła w 2002 roku prof. A. Kusińska, nie były kontynuowane w szerokim zakresie. W okresie 2010-2012 wobec narastajacego procesu starzenia się ludności Polski prof. M. Bombol i T. Słaby podjęły badania, mając świadomość konieczności szybkiego rozpoznania rynku dóbr i usług skierowanych do seniorów. W następnych latach badacze tego zjawiska musieli działać, nadal mając do dyspozycji niewielkie zaplecze finansowe, dlatego ograniczyli liczebność 
prób i do badań wybierali określoną lokalizację czy grupę społeczną. Badania rdzennej ludności wiejskiej, prowadzone przez czteroosobowy zespół SGH (2016 r.), są przykładem docierania do kolejnej białej plamy w badaniach poziomu życia polskich seniorów. Literatura przedmiotu w Polsce, dotycząca warunków życia i potrzeb seniorów, daje przedsiębiorstwom szansę na podejmowanie różnych działań.

W rozdziale pierwszym rekomendowanej książki na podstawie źródeł wtórnych dokonano rzetelnego przeglądu podstawowych definicji. Autor dokonał ich syntezy i omówił różne wymiary odnoszące się do tego etapu w życiu człowieka - etapu trudnego ze względu na uwarunkowania biologiczne, psychologiczne i społeczne, wpływające na zachowania rynkowe seniorów. Przedstawione w nim treści stanowią cenne wskazówki dla producentów dóbr i usług.

W rozdziale drugim zidentyfikowano cel poznawczy pracy, czyli omówienie innowacyjności produktu, ze szczególnym podkreśleniem istotnej roli innowacji wprowadzanych w procesie zarządzania w odniesieniu do trudnej grupy odbiorców, jaką stanowią seniorzy. W kontekście cech tej grupy konsumentów liczba determinant różnicujących ich decyzje zakupowe jest bowiem silnie zróżnicowana, zaś samych decyzji nie można opierać na pojęciu przeciętnego seniora.

Rozdziały trzeci i czwarty poświęcono prezentacji metodyki badań empirycznych oraz jej wyników uzyskanych dzięki zaangażowaniu solidnego warsztatu analizy statystycznej, którym autor recenzowanej książki posługuje się niewątpliwie sprawnie. Wykazał on, że liczba i silne zróżnicowanie niedokonywania zakupów innowacyjnych produktów przez seniorów wywołują konieczność dalszych pogłębionych badań empirycznych. Podkreślił przy tym, że w dużym stopniu brak zainteresowania przedstawicieli tej grupy omawianą grupa produktów wynika z zachowawczych postaw seniorów, przywiązanych do tradycji.

Opracowany model zachowań polskich seniorów wobec nowych produktów FMCG zaprezentowano w rozdziale piątym recenzowanej publikacji.

Szczególnie użyteczna dla praktyki gospodarczej jest segmentacja konsumentów seniorów, uwzględniająca innowacje produktów na rynku FMCG. Wnioski z niej płynące nie są zbyt optymistyczne, ponieważ dowodza, że zainteresowanie seniorów nowymi produktami nie jest zbyt wielkie. To oznacza, że konieczne są dalsze badania, przede wszystkim identyfikujące determinanty zachowań seniorów w różnych grupach wiekowych, głównie w podziale na seniorów młodszych i starszych, wobec innowacji produktowych.

Analizując omawiane kwestie, należy także uwzględnić fakt, że rośnie liczba seniorów singli, co wywołuje określone zmiany w ich zachowaniach na rynku. Autor recenzowanej książki wskazuje te demograficzne i ekonomiczne zmiany w obszernym zakończeniu opracowania.

Publikacja Konsumenci seniorzy wobec innowacji produktowych poszerza wiedzę o zachowaniach polskich seniorów nie tylko na rynku FMCG. Producenci dóbr i usług muszą tę wiedzę zdobywać, bowiem segment konsumentów w wieku 60+ będzie wkrótce dominował na rynku. W związku z tym lekturę tej książki rekomenduję jako obowiązkową. 


\title{
Recenzenci współpracujący z czasopismem w 2018 roku
}

\author{
Daniel Álvarez \\ Grażyna Bortnowska \\ Ewa Czarniecka-Skubina \\ Jolanta Czarnocińska \\ Zbigniew Duda \\ Joanna M. Dziadkowiec \\ Krzysztof Firlej \\ Ewa M. Flaczyk \\ Pasquale Giungato \\ Małgorzata Gniewosz \\ Marzena Jeżewska-Zychowicz \\ Joanna Kawa-Rygielska \\ Małgorzata K. Kowalska \\ Grażyna Krasnowska \\ Wanda Kudełka \\ Lech Krzysztof \\ Bogusława Łapczyńska-Kordon \\ Monika Michalczuk \\ Katarzyna M. Mikołajczyk-Bator \\ Dariusz Piotrowski \\ Ryszard Polechoński \\ Stanisław Popek \\ Waldemar Rymowicz \\ Barbara Sawicka \\ Katarzyna Szczepańska \\ Maria Śmiechowska \\ Joanna Wyka
}




\section{Autorzy współpracujący z czasopismem w 2018 roku}

Grażyna Bortnowska: Characteristics of aroma compounds and selected factors shaping their stability in food with reduced fat content

Grażyna Bortnowska: Ocena składu recepturowego dań obiadowych ready to eat poddanych pasteryzacji

Tadeusz Borys: Rekomendacja książki pt. Systemy zarzq̨dzania w znormalizowanym świecie pod redakcją naukową Jerzego Łańcuckiego

Aleksandra Chuda, Krzysztof Ziemiński: Wpływ wysokich stężeń azotu na biologiczne oczyszczanie ścieków cukrowniczych (1)

Ewa Czarniecka-Skubina, Artur Głuchowski: Turystyka gastronomiczna - fakty i mity

Zenon Foltynowicz, zob. Tomasz Lesiów, Zenon Foltynowicz

Karolina Gadzała, Agata Wypchły, Tomasz Lesiów: Wykorzystanie metody projektu w doskonaleniu jakości produktów żywnościowych

Aleksandra Garaszczuk, zob. Agnieszka Orkusz, Aleksandra Garaszczuk

Artur Głuchowski, zob. Ewa Czarniecka-Skubina, Artur Głuchowski

Magdalena Gniedziejko, Tomasz Lesiów: Zachowania konsumenckie związane z wyborem mlecznych produktów light i ich uwarunkowania

Zuzanna Goluch, Piotr Nabiałek: Znaczenie płynów w diecie turysty

Marcin Ignaczak, zob. Dariusz Piotrowski, Marcin Ignaczak

Monika Janowicz: Rekomendacja książki pt. Inżynieria procesowa i aparatura przemystu spożywczego pod redakcją naukową Piotra P. Lewickiego

Malgorzata A. Jarossová, Lubica Knošková: Pro-ecological activities of Slovak hotels in the opinion of their employees and consumers

L'ubica Knošková, zob. Malgorzata A. Jarossová, Lubica Knošková

Tomasz Lesiów, Zenon Foltynowicz: Opakowania funkcjonalne w żywności

Tomasz Lesiów, zob. Karolina Gadzała, Agata Wypchły, Tomasz Lesiów

Tomasz Lesiów, zob. Kornelia Muss, Tomasz Lesiów

Tomasz Lesiów, zob. Magdalena Gniedziejko, Tomasz Lesiów

Kornelia Muss, Tomasz Lesiów: System szybkiego informowania o niebezpiecznych produktach nieżywnościowych - RAPEX

Kornelia Muss, Tomasz Lesiów: System wczesnego ostrzegania przed niebezpiecznymi zanieczyszczeniami żywności: biologicznymi, organicznymi i/lub nieorganicznymi związkami chemicznymi oraz przeciwdziałanie fałszowaniu żywności

Piotr Nabiałek, zob. Zuzanna Goluch, Piotr Nabiałek

Agnieszka Orkusz, Aleksandra Garaszczuk: Gluten w żywności - korzyści i zagrożenia

Agnieszka Orkusz, zob. Paulina Suchodolska, Agnieszka Orkusz

Dariusz Piotrowski, Ignaczak Marcin: Influence of pressure in vacuum drying chamber on shrinkage of defrosted strawberries

Mirosława Pluta-Olearnik: Recenzja książki pt. Komunikacja międzykulturowa w biznesie autorstwa Grażyny Rosy, Izabeli Ostrowskiej, Kamili Słupińskiej, Leszka Gracza 
Tuğçe Sevil Yaman: Effects of the 4th industrial revolution on civil engineering with special emphasis on structural engineering - the case of Germany

Teresa Słaby: Rekomendacja książki Tomasza Olejniczka pt. Konsumenci seniorzy wobec innowacji produktowych

Paulina Suchodolska, Agnieszka Orkusz: Otyłość - przyczyny, rodzaje, leczenie, skutki

Maria Śmiechowska: Czynniki wpływające na atrakcyjność kwiatów jadalnych

Agata Wypchły, zob. Karolina Gadzała, Agata Wypchły, Tomasz Lesiów

Krzysztof Ziemiński, zob. Aleksandra Chuda, Krzysztof Ziemiński 